\title{
Prevalence of Metabolic Syndrome among Kaingang Native Americans in Southern Brazil
}

\author{
Heloisa Nakai Kwabara dos Anjos ${ }^{1}$, Max Jean de Ornelas Toledo ${ }^{2}$, Lúcio Tadeu Mota ${ }^{3}$, \\ Isolde Terezinha Santos Previdelli ${ }^{4}$, Adriano Félix dos Anjos ${ }^{1}$, Tiago Ribeiro Saruhashi ${ }^{1}$, \\ Márcia Aparecida Carrara ${ }^{1}$ and Márcia Regina Batista ${ }^{1 *}$ \\ ${ }^{I}$ Departamento de Análises Clínicas; ${ }^{2}$ Departamento de Ciências Básicas de Saúde; ${ }^{3}$ Departamento de História; \\ ${ }^{4}$ Departamento de Estatística; Universidade Federal de Maringá - Maringá - PR - Brasil
}

\begin{abstract}
The aim of this work was to evaluate the prevalence of metabolic syndrome, diabetes mellitus, and obesity among a Brazilian indigenous population. A cross-sectional study was carried out in 2008 among Kaingang native Americans from the central region of the state of Paraná, Brazil. Eighty two of the inhabitants aged 15 or older were selected. Height, weight, blood pressure, waistline circumference, and hip circumference were measured. After fasting, the blood was collected for the measurement of glucose, HDL cholesterol, triglyceride, total cholesterol, AI and $B$ apolipoprotein, and hemoglobin. The prevalences found were: fasting hyperglycemia (9.8\%), hypercholesterolemia (4.9\%), reduced HDL cholesterol (13.4\%), hypertriglyceridemia (11\%), abdominal obesity (37.8\%), generalized obesity (26.8\%), arterial hypertension (26.8\%), and anemia (46.3\%). The prevalence of Metabolic Syndrome among the Kaingang was 11\%, all in females 20 to 49 years of age. The results suggested that the changes in the indigenous lifestyle, especially in eating habits and physical activity, have occurred.
\end{abstract}

Key words: Metabolic syndrome, health of indigenous peoples, Brazilian native Americans, Kaingang

\section{INTRODUCTION}

It is estimated that 20 to $25 \%$ of the world population has Metabolic Syndrome (Borges et al., 2007). In the United States of America, the prevalence is $24 \%$ among the adults (Ford et al., 2002). In Brazil, the First Brazilian Guideline for Diagnosis and Treatment of Metabolic Syndrome (Sociedade Brasileira de Hipertensão, 2004) (MS) reported that there were no representative data on the prevalence of Metabolic Syndrome in the population of Brazil.

There are no global data about the health situation of the Brazilian indigenous peoples. The only partial data available were provided by the BNIF (Brazilian National Indian Foundation), BNHF (Brazilian National Health Foundation), and many other non governmental organizations (FUNASA, 2000). Data concerning their nutritional situation are particularly few. This deserves attention, since the nutritional status is highly influenced by the economic, social, and cultural transformations, as well as by the alterations in subsistence strategies, food consumption, and physical-activity patterns. Such changes are relatively common in the daily lives of indigenous groups that interact with the larger society (Gugelmin \& Santos, 2001).

*Author for correspondence: mrbatista@uem.br 
The Brazilian indigenous population numbers around 400,000 . They belong to about 215 groups, and speak over 180 identified languages (FUNASA, 2008). According to the SocioEnvironmental Institute, which evaluated the BNHF data from 2003, it is estimated that 25,875 native Americans from the Kaingang ethnic group live in Indigenous Lands (Instituto SócioAmbiental, 2007). Although this group is in permanent contact with the larger society, little is known about the health profile of this population. Improvements in health services and the adaptation of these services to the socio-cultural characteristics of these groups require a better knowledge of their health profiles. Taking this into consideration, researchers from the State University of Maringá (SUM) have been determining several health indicators in the population living in the Faxinal Indigenous Land, Paraná, Brazil. It has been observed that the respiratory infectious, and parasitic diseases are among the main causes of morbidity in this population. Bonani (2008) carried out an anthropometric study of Kaingang children from 0 to 9 years old, and observed a prevalence of obesity of $3.95 \%$ among the girls and $2.30 \%$ among the boys.

As part of this general study, the present research evaluated, for the first time, the prevalence of MS among the Kaingangs. The prevalences of diabetes mellitus and obesity were also estimated.

\section{MATERIALS AND METHODS}

A cross-sectional study was carried out during the first semester of 2008 among the members of the Kaingang tribe from the Faxinal Indigenous Land, located in the city of Cândido de Abreu, in the central region of Paraná. The area is 2,043 hectares in extent, and the population numbers about 472 (Instituto Sócio-Ambiental, 2007). Eighty two of the 239 inhabitants aged 15 years or older were randomly selected for the study. Height, weight, blood pressure, waistline circumference (WC), and hip circumference (HC) were measured. Blood pressure (BP) was measured using a standard mercury phygmomanometer, after the subject had been sitting for at least $5 \mathrm{~min}$ with the arm resting at heart level. The mean of two blood-pressure measurements was used. The brachial artery was located along the inner upper arm by palpation, and the bladder was centered on it. The stethoscope position was over the palpated brachial artery below the cuff at the antecubital fossa. The SBP (Systolic Blood Pressure) was determined by phase I of Korotkoff sounds (onset of at least two consecutive beats), and the DBP (Diastolic Blood Pressure) was determined at the cessation of the Korotkoff sounds (phase V). The subjects with a BP value above $130 \times 85 \mathrm{~mm} \mathrm{Hg}$ were considered hypertensive.

After a 12-h fast, blood was collected for the following examinations: glucose, HDL cholesterol, triglyceride, total cholesterol, AI and $\mathrm{B}$ apolipoprotein, and hemoglobin). The BMI (Body Mass Index) was calculated using the formula Weight $(\mathrm{Kg}) / \mathrm{Height}^{2}\left(\mathrm{~m}^{2}\right)$, and the waisthip ratio using the formula $\mathrm{WC} / \mathrm{HC}$.

Laboratory dosages were performed through the Merck Vitalab Selectra ${ }^{\circledR} 2$ automatic analyzer. Total cholesterol (TC), triglyceride (TGC), and glucose (GLU) levels were determined through Enzymatic Colorimetric methodology (Cholesterol FS Diasys, Triglycerídes FS Diasys, Glucose GOD Diasys); HDL cholesterol through enzyme immunoassay (ELISA) methodology (HDL-Chol. Dir. Immuno FS Diasys); and AI and B Apolipoprotein through the turbidimetric immunology method (APO AI Diasys and APO B Diasys). The data analysis consisted of comparing the levels of metabolites with reference values, and calculating the prevalence of altered levels. The odds ratio was estimated by a Univariate Logistical Regression analysis, testing the statistical significance using $\mathrm{R}$ Software, version 2.7.0.

The study was approved by the Permanent Committee for Ethics in Research of the State University of Maringá (PCER) and by the National Committee for Ethics in Research (NCER) (document \#156/2008). BNHF provided the authorization for the research on the indigenous people, and BNIF authorized the entry into the Indigenous Land. The local chief and the members of the community also granted authorization. All the participants in the research signed the Free and Informed Consent Form. In addition, every action carried out in the Indigenous Land (including obtaining the Consent Form) was monitored by a community representative (indigenous health agent), who also acted as an interpreter. 


\section{RESULTS}

Fourty nine (59\%) of the 82 native Americans who took part in the study were female and $33(41 \%)$ were male. Their ages ranged from 15 to 70 years, with 20 to 29 the most prevalent. The mean age was 32. The prevalence of altered fasting glycemia ( $\geq 100 \mathrm{mg} / \mathrm{dl}$ values) was $9.8 \%$, including seven women and one man (Table 1). None of the subjects showed fasting glycemia levels above 126 $\mathrm{mg} / \mathrm{dl}$. Of the seven women, two were in the 20 to 29 age group, four were in the 40 to 49 group, and one was 70 years old. The only man who showed glycemia above $100 \mathrm{mg} / \mathrm{dl}$ was 20 years old. The mean level of glycemia in this population was 84.7 $\mathrm{mg} / \mathrm{dl}(\leq 99 \mathrm{mg} / \mathrm{dl}$ reference value).

The prevalence of hypertriglyceridemia was $11 \%$ (nine people), of whom six were women in the 28 to 44 age group and three were men, one of them only 15 years old and the other two in the 30 to 43 age group. The mean triglyceride level in this population was $103.8 \mathrm{mg} / \mathrm{dl} \quad(\leq 150 \quad \mathrm{mg} / \mathrm{dl}$ reference value).

For serum HDL, $13.4 \%$ of the individuals showed HLD values below the recommended levels for their age; all were women in the 20 to 49 age group. The mean population level of HDL was $53.9 \mathrm{mg} / \mathrm{dl}$ (reference value for women, > 50 $\mathrm{mg} / \mathrm{dl}$; for men, > $40 \mathrm{mg} / \mathrm{dl}$ ).

Abdominal obesity was one of the factors included in the evaluation of body-fat deposition. It was measured by the waistline circumference, which was elevated in $37.8 \%$ of the population, more often in women $(59.2 \%)$ and most common in 20to 50-year-old women. The mean value of $\mathrm{WC}$ for women was $90.1 \mathrm{~cm}$, and for men, $85.9 \mathrm{~cm}$ (reference values: up to $88 \mathrm{~cm}$ for women / up to $102 \mathrm{~cm}$ for men).

Table 1 - Prevalences of variables studied.

\begin{tabular}{lccc}
\hline Risk factor & Women n (\%) & Men n (\%) & Total n (\%) \\
\hline Altered fasting glycemia & $7(14.1 \%)$ & $1(3.0 \%)$ & $8(9.8 \%)$ \\
Hypertriglyceridemia & $6(12.2 \%)$ & $3(9.1 \%)$ & $9(11 \%)$ \\
Reduced HDL cholesterol & $11(22.4 \%)$ & $0(0 \%)$ & $11(13.4 \%)$ \\
Abdominal obesity & $29(59.2 \%)$ & $2(6.1 \%)$ & $31(37.8 \%)$ \\
Arterial hypertension & $14(28.6 \%)$ & $8(24.2 \%)$ & $22(26.8 \%)$ \\
Metabolic syndrome & $9(18.4 \%)$ & 0 & $9(11 \%)$ \\
Hypercholesterolemia & $2(4.1 \%)$ & $2(6.1 \%)$ & $4(4.9 \%)$ \\
ApoB / ApoAI ratio & $28(57.1 \%)$ & $12(36.4 \%)$ & $40(48.8 \%)$ \\
Waist-hip ratio & $34(69.4 \%)$ & $11(33.3 \%)$ & $45(54.9 \%)$ \\
Overweight $\left(\mathrm{BMI} \geq 25 \mathrm{~kg} / \mathrm{m}^{2}\right)$ & $16(32.6)$ & $15(45.5)$ & $31(37.8)$ \\
Obesity (BMI $\left.\geq 30 \mathrm{~kg} / \mathrm{m}^{2}\right)$ & $17(34.7)$ & $5(15.1)$ & $22(26.8)$ \\
Anemia & $22(44.9 \%)$ & $16(48.5 \%)$ & $38(46.3 \%)$ \\
\hline
\end{tabular}

Apo B indicates apolipoprotein B; Apo AI, apolipoprotein AI; BMI, Body Mass Index.

Twenty two $(26.8 \%)$ of the subjects showed hypertension, including 14 (63.6\%) women and eight $(36.4 \%)$, men. Among the women, $28.6 \%$ were hypertensive $24.2 \%$ of the men were hypertensive (reference values: < 130 x $85 \mathrm{~mm}$ $\mathrm{Hg}$ ).

The MS was evaluated utilizing the criteria of the National Cholesterol Education Program/Adults Treatment Panel III (NCEP/ATP III, 2001), in which three or more risk factors were considered (hyperglycemia, reduced HDL, hypertriglyceridemia, abdominal obesity, and arterial hypertension). Among the eighty two subjects evaluated, nine had the syndrome ( $11 \%$ of the indigenous population); all of them were women in the 20 to 49 age group.

Considering the total serum cholesterol, only $4.9 \%$ showed levels above those recommended. Only the subjects under 20 years old showed normal values. Among the individuals over 20, two women in the 40 to 49 age group and two men (a 29-year-old and a 59-year-old) showed an increase. The mean level of cholesterol in the population was $163.6 \mathrm{mg} / \mathrm{dl}$ (reference value: < $200 \mathrm{mg} / \mathrm{dl})$.

The blood concentration of the apolipoprotein (Apo AI and Apo B) was also verified: $14.6 \%$ of the population showed reduced Apo AI, and 2.4\% 
showed increased Apo B. Alterations were prevalent in the younger age groups. Such a prevalence also occurred in the Apo B/Apo AI ratio; the mean values were $133.6 \mathrm{mg} / \mathrm{dl}$ (Apo AI) and $107.6 \mathrm{mg} / \mathrm{dl}$ (Apo B) for women, and 131.3 $\mathrm{mg} / \mathrm{dl}$ (Apo AI) and $103.3 \mathrm{mg} / \mathrm{dl}$ (Apo B) for men (reference values: Apo AI $>120 \mathrm{mg} / \mathrm{dl}$ in women and $>110 \mathrm{mg} / \mathrm{dl}$ in men; Apo B up to $150 \mathrm{mg} / \mathrm{dl}$ in women and up to $155 \mathrm{mg} / \mathrm{dl}$ in men). The prevalence of the ApoB/ApoAI ratio was $48.8 \%$ among this population, given that $57.1 \%$ of the women and $36.4 \%$ of the men showed an elevated ratio (reference values: up to 0.8 in women and up to 0.9 in men).

Altered values of WHR (Waist-hip ratio) were found in $54.9 \%$ of the subjects. The prevalence was, again, higher among the women (69.4\%). Among these, three were under 20 years old, eleven were in the 20 to 29 age group, eight were in the 30 to 39 age group, nine were in the 40 to 49 age group, and only three were in older age groups. Among men, one was under 20 years old, one in the 20 to 29 age group, three in the 30 to 39 age group, three in the 40 to 49 age group, two in the 50 to 59 age group, and only one over 60 years old. The mean WHR values were 0.89 and 0.90 for women and men, respectively (reference values: below 0.85 in women and below 0.90 in men).

The $64.6 \%$ of the population showed inadequate values of BMI (overweight and obesity), including $62.3 \%$ of the women and $37.7 \%$ of the men. The
$32.6 \%$ of the women were overweight (BMI between 25.0 and $29.9 \mathrm{~kg} / \mathrm{m}^{2}$ ) and $34.7 \%$ were obese $\left(B M I \geq 30 \mathrm{~kg} / \mathrm{m}^{2}\right)$. The $60.6 \%$ of the men showed altered values: $45.5 \%$ were overweight and $15.1 \%$ were obese. None of the subjects was underweight. The mean BMI was $27.8 \mathrm{~kg} / \mathrm{m}^{2}$ and $25.9 \mathrm{~kg} / \mathrm{m}^{2}$ for women and men, respectively.

During the logistical regression analysis, because of the small sample obtained (nine people with the syndrome), the odds ratio was calculated individually for each risk factor. The calculation of the odds ratio (Table 2), indicated that the subjects with fasting glycemia of $100 \mathrm{mg} / \mathrm{dl}$ or above had an approximately 6.79 times greater chance of presenting SM than those who showed normal levels $(\mathrm{p}=0.0234)$. Individuals who had total cholesterol concentrations at or above the desired levels had a 1.14 times greater chance of developing MS than did those who maintained the desired levels $(p=0.312)$. Similarly, the individuals who had HDL levels at or below that recommended for their age group had a 27.19 greater chance of developing MS compared to the others, with a significant $p$-value $(p<0.0001)$. For triglyceride, the obtained $\mathrm{p}$-value was also significant $(\mathrm{p}<0.0001)$, indicating that the individuals with increased triglyceride levels, had a 46.66 times greater chance of developing the syndrome compared to individuals who showed normal levels of this metabolite.

Table 2 - Odds ratio for each risk factor in Kaingang native Americans.

\begin{tabular}{|c|c|c|c|c|}
\hline Parameters & Reference values & p-value & Odds Ratio & CI (Odds;95\%) \\
\hline Age & $>19$ years old & 0.992 & $\begin{array}{ll}---- \\
\end{array}$ & $\begin{array}{ll}---- \\
\end{array}$ \\
\hline Gender & Female & 0.992 & ----- & ----- \\
\hline Glycemia & $\geq 100 \mathrm{mg} / \mathrm{dl}$ & 0.0234 & 6.79 & $1.28-35.65$ \\
\hline Total cholesterol & $\begin{array}{l}\text { Adults } \geq 200 \mathrm{mg} / \mathrm{dl} \\
\text { Young } \geq 170 \mathrm{mg} / \mathrm{dl}\end{array}$ & 0.0312 & 1.14 & $1.25-82.0$ \\
\hline HDL cholesterol & $\begin{array}{c}\text { Adult Men }<40 \mathrm{mg} / \mathrm{dl} \\
\text { Adult Women }<50 \mathrm{mg} / \mathrm{dl}\end{array}$ & $<0.0001$ & 27.19 & $5.18-142.6$ \\
\hline Triglyceride & $\begin{array}{l}\text { Adults } \geq 150 \mathrm{mg} / \mathrm{dl} \\
\text { Young }>130 \mathrm{mg} / \mathrm{dl}\end{array}$ & $<0.0001$ & 46.66 & $7.67-283.58$ \\
\hline Apo AI & $\begin{array}{c}\text { Men } \leq 110 \mathrm{mg} / \mathrm{dl} \\
\text { Women } \leq 120 \mathrm{mg} / \mathrm{dl}\end{array}$ & 0.228 & ----- & ----- \\
\hline Apo B & $\begin{array}{c}\text { Men } \leq 155 \mathrm{mg} / \mathrm{dl} \\
\text { Women } \leq 150 \mathrm{mg} / \mathrm{dl}\end{array}$ & 0.582 & ----- & ----- \\
\hline $\begin{array}{l}\text { Waistline } \\
\text { circumference }\end{array}$ & $\begin{array}{l}\text { Men } \geq 102 \mathrm{~cm} \\
\text { Women } \geq 88 \mathrm{~cm}\end{array}$ & 0.994 & ----- & ----- \\
\hline BMI & $\geq 25$ & 0.993 & ----- & ---- \\
\hline Blood pressure & $\geq 130 \times 85 \mathrm{~mm} \mathrm{Hg}$ & 0.0234 & 6.79 & $1.29-35.65$ \\
\hline
\end{tabular}

CI indicates Confidence interval; Apo AI, apolipoprotein AI; Apo B, apolipoprotein B; BMI, Body Mass Index. 
For the subjects with blood pressure above $130 \mathrm{x}$ $85 \mathrm{~mm} \mathrm{Hg}$, the chance of developing MS was almost 6.79 times higher than for those who did not show evidence of arterial hypertension ( $\mathrm{p}=$ 0.0234). Age, gender, Apo A1, Apo B, waistline circumference (WC), and BMI were not statistically significant in the odds ratio for MS in this population.

\section{DISCUSSION}

The study of the metabolic profile of the native populations from South America has attracted the attention of researchers worldwide. However, the number of studies on the indigenous groups is still small, and some metabolic profiles are still unknown today. For example, the members of the Kaingang tribe in this study had not been previously evaluated for glycemia and lipidemia, even the older individuals who were at higher risk for cardiovascular disease.

In Venezuela, where cardiovascular disease (CVD) and diabetes mellitus (DM) are the first and fifth main causes of death, respectively, Case et al. (2006) found a low risk of developing DM, obesity, and CVD in the Waraó tribe. The authors related these results to eating habits and physical activity, which were still preserved in this culture. Therefore, the groups that maintain their lifestyle, eating, and cultural habits and have not become westernized, have a low risk of cardiovascular diseases and chronic non-communicable diseases, such as DM (Gimeno et al., 2007). However, this does not occur in the native populations that are undergoing the westernization process.

In Mexico, where DM has been the third-highest cause of death, Alvarado-Osuna et al. (2001) observed that the members of the Otomie tribe showed a $4.4 \%$ prevalence of DM. The authors suggested that the diet played a protective role, compared to the hybridized populations that lived in the urban areas and have a higher DM prevalence. Alvarado-Osuna et al. (2001) also noted that the abrupt changes in the diet of Otomies could favor hyperlipidemia and the emergence of CVD.

Leite et al. (2006) studied the nutritional profile of a Xavante group in Mato Grosso, Brazil, and mentioned 133 cases of DM. However, Gimeno et al. (2007) did not find any case of DM in Aruáks from Alto Xingu, Brazil. They did observe an increased prevalence of glucose intolerance, concluding that the metabolic profile of these native Americans had worsened after their contact with western society.

In this study, no case of DM was found among the Kaingang subjects. However, the fasting hyperglycemia rate was $9.8 \%$, mainly in the women aged 20 to 49 . Due to the lack of way previous data, it was impossible to determine if this pattern had changed in recent years. Nevertheless, the prevention effors apear suitable to keep these numbers from rising. This observation could be relevant considering that the Kaingang living in the Faxinal Indigenous Land were mainly young, $49.4 \%$ in the 0 to 15 age group.

Fewer men than women participated in this study because many men left early in the morning to work. Despite the small number of participants (34.3\% of the population over 15 years old), significant and previously unreported data on this population were obtained.

According to the calculated odds ratio, the individuals with altered levels of glucose had a 6.79 times greater chance of developing MS than those with normal levels. The prevalence rates of hyperlipidemias were $4.9 \%$ for hypercholesterolemia, $\quad 11 \%$ for hypertriglyceridemia, and $29.3 \%$ for dyslipidemias (hypercholesterolemia, hypertriglyceridemia, or low HDL cholesterol). These results were similar to those for Guarani-Mbyá native Americans in Rio de Janeiro (Cardoso et al., 2001), but were lower than those obtained by Gimeno et al. (2007), who studied the metabolic profile of Aruák indians in Alto Xingu. For the individuals with hypercholesterolemia, hypertriglyceridemia, and lower HDL, the chances of developing MS were $1.14,46.66$ and 27.19 times greater, respectively. Nowadays, the plasma levels of AI and B apolipoproteins are considered to be better predictors of atherosclerotic diseases than the concentrations of lipid and lipoprotein. It has been suggested that the Apo B/Apo AI index is a better standard for the prediction of cardiovascular risk than other lipid indices such as total cholesterol, LDL/HDL, and non-HDL/HDL cholesterol (Lima et al., 2007).

In this study, it was observed that $48.8 \%$ of the population had altered Apo B/Apo AI indices, indicating a higher risk of CVD. In the INTERHEART study, where about 30.000 individuals from 52 countries were evaluated, the relationship of the Apo B/Apo AI index to the 
prediction of acute myocardial infarction proved to be stronger than many conventional risk factors such as tabagism, hypertension, DM, stress, and abdominal obesity, regardless of gender, age, and ethnic origin. In the AMORIS study (Apolipoprotein-related Mortality Risk), about 170.000 patients were evaluated, and it was demonstrated that Apo B was a better indicator of cardiovascular risk than LDL cholesterol, especially in the individuals with desired levels of LDL cholesterol, regardless of gender. The Apo B/Apo AI index was identified in the AMORIS study as the single variable that was most related to the risk of fatal acute myocardial infarction (AMI), mainly when lipidemia was in the desired range (Lima et al., 2007).

The overall prevalence of increased abdominal fat among the Kaingang (37.8\%) was a little lower than in the Guarani-Mbyá (Cardoso et al., 2001; 44.5\%) and Aruák (Gimeno et al., 2007; 52.1\%). However, the proportions were similar: higher in the females $(59.2 \%)$ than in the males $(6.1 \%)$. These proportions were found by these authors and also by Bloch et al. (1993) for the Yanomámi tribe in Roraima. Bloch et al. (1993) also found a correlation between the WC and capillary glucose, indicating that those with a higher abdominal circumference had higher glycemic levels. They suggested that one of the reasons why women had higher levels of glycemia was their higher average abdominal circumference. They also quoted many investigators who have indicated central body fat as a risk factor for glucose intolerance, type $2 \mathrm{DM}$, and CVD, regardless of the presence or degree of obesity.

Gulgelmin et al. (2006) compared the BMI with body composition measurements to check if BMI could be used to characterize the overweight and obesity in Xavantes. These authors concluded that the BMI had a higher correlation with the anthropometric measurements that indicated the body fat accumulation, and that it could be used in native Americans, including the young adults, as a parameter to evaluate the risks of obesity and CVD. For this reason, although this was a different population, and also because of the ease of collecting the data through this methodology, the BMI was chosen to evaluate the rate of obesity and overweight among the Kaingang.

The observed prevalence of $64.6 \%$ overweight and obesity was even higher compared to the overall prevalence in the capital of Paraná, which was one of the highest in Brazil (40.7\%). Only the cities of
Rio de Janeiro, Porto Alegre, and São Paulo showed higher rates (Ministério da Saúde, 2008). The prevalence of overweight/obesity was comparable to other indigenous populations. Arruda et al. (2003), for expample, found that $68.1 \%$ of Parkatejê and $72.5 \%$ of Kikatejê subjects in southeast Pará, in the Amazon rainforest, were overweight.

Altered BMI was more prevalent in women than in men ( 67.3 and $60.6 \%$, respectively).The $34.7 \%$ of women and $15.1 \%$ of men were in the over 30 $\mathrm{kg} / \mathrm{m}^{2} \mathrm{BMI}$ range, which characterized the obesity. However, $32.6 \%$ of women and $45.5 \%$ of men were in the 25 to $30 \mathrm{~kg} / \mathrm{m}^{2}$ BMI range, which characterized the overweight. Cardoso et al. (2001) obtained an overall overweight prevalence of $21.9 \%$, with $15.6 \%$ for the men and $29.0 \%$ for the women. The overall prevalence of obesity was $4.8-3.9 \%$ among the men and 5.8\% among the women. Leite et al. (2006) found that $69.9 \%$ of Xavante women and men were overweight, and $24.2 \%$ of the adults had a BMI of 30 or above (obesity), up to $19.2 \%$ in the men and $31.2 \%$ in the women. Capelli et al. (2001) evaluated the nutritional status of the members of the Parkatejê tribe from Pará in 1994. In this study, they found a prevalence of overweight of 50\% among the women and $23.7 \%$ among the men, and obesity rates of $12.5 \%$ and $1.7 \%$, respectively. This percentage indicated that more than half of the female population (62.5\%) had excess total body mass (World Health Organization -WHO, 1999). Gimeno et al. (2007) found that 51.8 and $15 \%$ of Aruáks were overweight or obese, respectively.

Young et al. (2007) analyzed the prevalence of obesity in Inuits in Canada, Greenland, and Alaska from 1990 to 2001 and found rates of overweight of $36.6 \%$ among the men and $32.5 \%$ among the women. These data were similar to the observations in the developed countries of Europe and North America. Interestingly, these data were also similar to the present findings.

Although these groups were in different stages of socio-cultural transformation, most of them showed a tendency to become epidemiologically similar in their metabolic and anthropometric profiles. If this trend persists, it is probable that new cases of chronic diseases such as type $2 \mathrm{DM}$ and CVD will appear.

Regarding the prevalence of arterial hypertension, Bloch et al. (1993) did not find compatible values with the arterial hypertension diagnosis in Yanomami from Roraima. Coimbra Jr. et al. 
(2001) reported that $5.3 \%$ of Xavante men and $7.7 \%$ of Xavante women from Pimentel Barbosa Indigenous Land in Mato Grosso suffered from the arterial hypertension. In a Guarani-Mbyá population from Rio de Janeiro, Cardoso et al. (2001) found an arterial hypertension percentage of $4.8 \%, 2.6 \%$ among the males and $7.4 \%$ among the females. Gimeno et al. (2007) recounted that in the 1960s, when researchers from the Escola Paulista de Medicina (Paulista Medical School) established a health assistance program for the native Americans in Xingu (an indigenous park), no individuals examined had high blood pressure. However, in the period from 1966 to 1971, Baruzzi \& Franco observed a 4\% increase in the prevalence of arterial hypertension among the males, while there was no alteration in the prevalence among the females. In a study carried out from 2000 to 2002, Gimeno et al. (2000/2002) found a hypertension prevalence of $37.7 \%$, indicating a substantial increase in the rate of arterial hypertension. In this study, the prevalence of hypertension was lower (26.8\%). However, a significant $p$-value was obtained for a 6.79 greater chance of having MS. In other words, the individuals who were hypertensive were 6.79 times likely to have MS than those who were normotensive.

In recent years, many have written (medical literature) or discussed about the MS. It combines a series of risk factors for cardiovascular disease, such as anthropometric indices, dyslipidemias, arterial hypertension, ad alterations in carbohydrate metabolism and pro-thrombotic and pro-inflammatory status. Premature coronary disease and high mortality rates for the cardiovascular reasons are associated with a high risk of type $2 \mathrm{DM}$. According to the Brazilian Diabetes Society (2006), the expectancy is that MS frequency would increase in the populations in this country, since many of the abnormalities that compose it are related to the modern lifestyle.

In 1999, the World Health Organization (WHO) proposed a list of criteria to define the MS, emphasizing the presence of type $2 \mathrm{DM}$, glucose intolerance, or insulin resistance, and two additional factors, which could be arterial hypertension, dyslipidemia, central or abdominal obesity, and microalbuminuria. In 2001, the NCEP/ATP III modified the criteria for MS classification, basically differing from the WHO on whether the evidence of insulin resistance or microalbuminuria measurement was necessary.
The modified criteria still emphasized, though, the importance of the presence of abdominal obesity. In this study, the NCEP/ATP III criteria were adopted for the calculation of MS prevalence, because the same criteria have been recommended by the Brazilian Diabetes Society (2004) and by the First Brazilian Guideline for Diagnosis and Treatment of the Metabolic Syndrome (Bloch et al., 1993). However, the reference value for fasting glycemia was adjusted to $100 \mathrm{mg} / \mathrm{dl}$, because in 1997, the American Diabetes Association (ADA) modified it, and the changed value was later accepted by the WHO and by the Brazilian Diabetes Society.

The NCEP/ATP III criteria for MS lipid alterations increase the number of diagnoses of hypertensive individuals, because their reference values are lower than the WHO criteria. Apart from the diagnostic criteria adopted for MS, every international organization recognizes the importance of investigating and treating each of the identified risk factors (Brazilian Hypertension Society, 2004).

Among the main implications of a MS diagnosis is the possibility of preventing the development of $\mathrm{DM}$ and CVD, intervening in each risk factor. This is because most of the risk factors respond positively to the modifications in lifestyle, weight reduction, healthy diet, and physical activity (Brazilian Hypertension Society, Sociedade Brasileira de Hipertensão, 2004).

The present results showed that the Kaingang, similarly to other indigenous groups, had modified their eating habits, reduced their physical activity, and adopted the behaviors that favored the development of chronic degenerative diseases. Such modifications seemed to impact the metabolic and anthropometric profile of the group as a whole. The presence of overweight, obesity, and central obesity, mainly among the women, was observed. In general, the women are responsible for the arts and crafts, which requires them to remain in a seated position for long the periods of time.

In addition to the reduction in physical activity, during the fieldwork, a high rate of consumption of alcoholic beverages and manufactured food, especially pasta, sweets, cookies, candy, bread, soda, chips, canned food, and oils was observed. The consumption of fruits was limited to seasonal fruits growing in the indigenous land, and the consumption of green vegetables depended on the financial resources. These changes in the feeding 
pattern certainly contribute to the high rates of overweight and obesity rate observed.

The sources of income for the Kaingang (subsistence agriculture, temporary work contracts, and the handicrafts trade) are not sufficient. The resulting substandard conditions in the indigenous land have placed at risk the quality of this community's diet. According to Pachú et al. (2003), low income tends to be a risk factor for obesity, since it is associated with a high-calorie diet, rich in fat, which favors the rise of CVD.

The prevalence of cardiovascular risk factors and chronic diseases such as DM is increasing in indigenous populations, and apparently the same has been occurring among the Kaingang from the Faxinal Indigenous Land. This conclusion is linked to the fact that, although this was a crosssectional study, a higher prevalence of MS in the younger age groups was observed. The women showed a higher prevalence of most of the risk factors evaluated, including the prevalence of MS. It is likely that these metabolic and anthropometric profiles are associated with the indigenous peoples' lifestyle, which has been largely transformed through the years by contact with the western society. The findings of this study have significant implications for the indigenous health assistance services. It would be possible to develop the strategies to improve the health of these native Americans.

\section{ACKOWLEDGMENTS}

We thank the residents of the Faxinal Indigenous Land for their participation. Our thanks also to Evaldo Silva do Nascimento, a nurse at the Basic Health Unit in the Faxinal Indigenous Land. Thanks to Labmax for donating the kits that were used in the study.

\section{REFERENCES}

Alvarado-Osuna C, Millan-Suazo F, Valles-Sanchez V. (2001), Prevalencia de Diabetes mellitus e hiperlipidemias em indígenas otomies. Salud Publ de Mex, 43(5), 459-463.

Arruda HO, Vieira Filho JPB, Ortiz V, et al. (2003), PSA e medidas antropométricas em índios da Amazônia: avaliação da comunidade Parkatejê. Rev Saude Publ, 37(5), 624-628.
Bloch KV, Coutinho ESF, Lôbo MSC, et al. (1993), Pressão arterial, glicemia capilar e medidas antropométricas em uma população Yanomámi. Cad Saude Publ, 9(4), 428-438.

Bonani AR. (2008), Estado Nutricional, Enteroparasitoses e Fatores Sócio-Econômicos e Materno-Infantis de Crianças Kaingang da Terra Indígena de Faxinal, Paraná, Brasil. Dissertação de Mestrado, Universidade Estadual de Maringá, Paraná, Brazil.

Borges PKO, Gimeno SGA, Tomita NE, et al. (2007), Prevalence and characteristics associated with metabolic syndrome in Japanese-Brazilians with and without periodontal disease. Cad Saude Publ, 23(3), 657-668.

Capelli JCS, Koifman S. (2001), Avaliação do estado nutricional da comunidade indígena Parkatêjê, Bom Jesus do Tocantins, Pará, Brasil. Cad Saude Publ, 17, 433-437.

Cardoso AM, Mattos IE, Koifman RJ. (2001), Prevalência de fatores de risco para doenças cardiovasculares na população Guaraní-Mbyá do Estado do Rio de Janeiro. Cad Saude Publ, 17, 345354.

Case C, Palma A, Brito S, et al. (2006), Factores de riesgo asociados a Diabetes mellitus tipo 2 em índios Waraos del Delta Amacuro, Venezuela. Interciencia, 31(4), 309-311.

Coimbra Jr, CEA, Chor D, Santos RV, et al. (2001), Blood pressure levels in Xavante adults from the Pimentel Barbosa Reservation, Mato Grosso, Brazil. Ethn Dis, 11(2), 232-240.

Delatore S. (2007), Morbidade ambulatorial da população Kaingang das Terras Indígenas Faxinal e Ivaí, Estado do Paraná, 2001 a 2004. Dissertação de Mestrado, Universidade Estadual de Maringá, Paraná, Brazil.

Ford ES, Giles WH, Dietz WH. (2002), Prevalence of the metabolic syndrome among US adults: findings from the third National Health and Nutrition Examination Survey. JAMA, 287, 356-359.

FUNASA (Fundação Nacional de Saúde). Política Nacional de atenção à saúde dos povos indígenas [funasa.gov.br Web site].(2000). Available at: http://www.funasa.gov.br/internet/Bibli_saudeInd.asp Accessed May 13,2007.

FUNASA (Fundação Nacional de Saúde). Saúde indígena [funasa.gov.br Web site]. (2008). Available at: $\quad$ http://www.funasa.gov.br/internet/saude Indigena.asp. Accessed October 21, 2008.

Gimeno SGA, Rodrigues D, Pagliaro H, et al. (2007), Perfil metabólico e antropométrico de índios Aruák: Mehináku, Waurá e Yawalapiti, Alto Xingu, Brasil Central, 2000/2002. Cad Saude Publ, 23(8), 19461954 
Gugelmin SA, Santos RV. (2001), Ecologia humana e antropometria nutricional de adultos Xavánte, Mato Grosso, Brasil. Cad Saude Publ, 17, 313-322.

Gugelmin SA \& Santos RV. (2006), Uso do índice de massa corporal na avaliação do estado nutricional de adultos indígenas Xavante, Terra Indígena Sangradouro-Volta Grande, Mato Grosso, Brasil. Cad Saude Publ, 22(9), 1865-1872.

Instituto Sócio-Ambiental. Povos indígenas no Brasil: quem, onde, quantos. [Instituto Sócioambiental.org Web site]. March, (2007). Available at: http:// www.socioambiental.org. Accessed July 22, 2007.

Leite MS, Santos RV, Gugelmin SA, et al. (2006), Crescimento físico e perfil nutricional da população indígena Xavante de Sangradouro-Volta Grande, Mato Grosso, Brasil. Cad Saude Publ, 22(2), 265276.

Lima LM, Carvalho MG, Sousa MO. (2007), Índice Apo B/Apo A-1 e Predição de Risco Cardiovascular. Arq Bras Cardiol, 88(6), e187-e190.

Ministério da Saúde. Indicadores e dados básicos para a saúde - IDB 2007 [saúde.gov.br Web site]. (2007). Available at: http:// www.datasus.gov.br/idb. Accessed July 15, 2008.

National Cholesterol Education Program. (2001), Expert panel on detection, evaluation, and treatment of high blood cholesterol in adults (Adult Treatment Panel III). JAMA, 285, 2486-2497.

Pachú CQ, Silva R, Rondinelli E, et al. (2003), Obesidade, genes e meio ambiente na complexa rede causal da doença cardiovascular aterotrombótica. Rev SOCERJ, 16(2), 204-209.
SOCIEDADE BRASILEIRA DE DIABETES. Atualização Brasileira sobre Diabetes [diabetes.org.br Web site]. (2006). Available at: http://www.diabetes.org.br/politicas/abdonline.php. Accessed June 3, 2007.

Sociedade Brasileira de Hipertensão. (2004), I Diretriz Brasileira de Diagnóstico e Tratamento da Síndrome Metabólica. Hipertensão, 7(4), 123-159.

Toledo F. (2007), A infecção da população e a contaminação do solo por enteroparasitos em Terras Indígenas Kaingang após medidas de controle. Dissertação de Mestrado, Universidade Estadual de Maringá, Paraná, Brazil.

World Health Organization (WHO). (1999), World Health Organization. Part 1: Diagnosis and Classification of Diabetes Mellitus: Report of a WHO consultation. In: Alwan A, King H, eds. Definition, diagnosis and classification of diabetes mellitus and its complications. Geneva: World Health Department of Noncommunicable Disease Surveillance, 1-59.

Young TK, Bjeegaard P, Dewailly E, et al. (2007), Prevalence of obesity and its metabolic correlates among the circumpolar inuit in 3 countries. Am J Public Health, 97(4), 691-695. 